\title{
The genus Tristachya (Poaceae: Panicoideae) in Madagascar
}

\author{
Maria S. Vorontsova ${ }^{1}$ (D) \& Nantenaina H. Rakotomalala ${ }^{2}$
}

Summary. We present a revision of the three species of Tristachya in Madagascar. The tussock-forming T. betsileensis is a rare endemic of the quartz outcrops in the Itremo Protected Area. The rhizomatous T. isalensis and T. humbertii are common components of the sandstone outcrop vegetation in the Isalo National Park. A new combination is made. Descriptions, conservation assessments, illustrations, and a distribution map are presented.

Key Words. Africa, conservation, grass, identification key, new combination, savanna, Tristachyideae.

\section{Introduction}

The genus Tristachya sensu lato (sometimes including Dilophotriche, Loudetiopsis, and Zonotriche) unites an estimated forty primarily African tropical savanna grasses that are usually easy to recognise by their large spikelets arranged in groups of three (Clayton \& Renvoize 1986; Kellogg 2015; Soreng et al. 2017). Variability in the spikelet arrangement, upper floret callus, and indumentum has led to a complex history of generic classifications within this group, all members of which are currently recognised within the tribe Tristachyideae Sánchez-Ken \& L.G.Clark, subfamily Panicoideae (Clayton \& Renvoize 1986; Sánchez-Ken \& Clark 2010; Kellogg 2015; Soreng et al. 2017). Like many African grasses, no monographic or revisionary work has recently been attempted beyond regional floras (e. g. Clayton et al. 1974; Fish et al. 2015), and to date there is no agreement on the delimitation of the genus Tristachya between Clayton et al. (2016), Kellogg (2015) and Soreng et al. (2017). Glumes of the African and Malagasy Tristachya exhibit macrohairs with distinctive black pustules at the base (Figs 1F, 2A; Kellogg 2015): these are usually referred to as bulbous-based or tubercle-based hairs (Clayton et al. 1974; Fish et al. 2015).

The ancestors of Malagasy Tristachya arrived on the island from Africa an estimated 5- $7 \mathrm{Ma}$ (Hackel et al. 2018), during the early part of the Miocene C4 grassland expansion (Edwards et al. 2010). The first two species were described by Aimée Camus in the genus Tristachya (Camus 1926, 1957). The third was described in the genus Danthoniopsis (Camus 1958, 1960) and has no combination in Tristachya. All three were united into the endemic Malagasy genus Isalus by Phipps
(1966), distinguished by its $6-8$ tufts of hair and bristled lobes on the upper lemma. The genus Isalus was accepted by Bosser (1969). This Malagasy radiation was then shown to be embedded within Tristachya by Hackel et al. (2018). We therefore follow Clayton \& Renvoize (1986) in recognising these three species within the larger genus Tristachya.

Grass surveys of the Itremo Protected Area (Nanjarisoa et al. 2017) and the Isalo National Park (Rakotomalala et al. 2021) have enabled us to compile field observations suggesting that all three species are associated with rocky outcrops and adapted to fires, with rapid resprouting after fire; herbarium specimens of all the species commonly exhibit charring. A full specimen survey was carried out at K, P, and TAN herbaria. We summarise the current knowledge of Tristachya in Madagascar and publish the missing combination, alongside an identification key, typifications, species descriptions, illustrations, and a distribution map. All specimens cited were seen by the authors.

Tristachya Nees (Nees von Esenbeck 1829: 458). Lectotype: Tristachya leiostachya Nees, designated by Swallen (in Hitchcock et al. 1939: 578).

Isalus J.B.Phipps (1966: 232).

Long-lived perennials with contracted or elongated woody underground rhizomes. Inflorescence terminal, a simple or branched panicle. Spikelets bisexual, arranged in dense triads of 3 identical spikelets subtended by an inflorescence branch. Glumes persistent, chartaceous. Lower glume positioned on the outside of the triad, long-acuminate, 3-nerved, with

Accepted for publication 7 May 2021. Published online 25 November 2021

1 Comparative Plant \& Fungal Biology Department, Royal Botanic Gardens, Kew, Richmond, Surrey, TW9 3AE, UK. e-mail: m.vorontsova@kew.org

2 Kew Madagascar Conservation Centre, Antananarivo, Madagascar. 
bulbous-based hairs. Upper glume similar to the lower glume but with few or no bulbous-based hairs. Lower floret sterile. Lower lemma membranous to chartaceous, shorter or somewhat longer than the glumes, 3 - 5-nerved. Upper floret bisexual, disarticulating on maturity. Upper lemma cylindrical, crustaceous, inrolled, with a fringe of white cilia c. 2/3 of the way up, the callus pungent, the apex bilobed with the awn originating between the two mucronate lobes. Awn twisted, geniculate.

\section{Key to Malagasy Tristachya species}

1. Tussock-forming (rhizomes contracted); leaves originate from the base of the plant, leaf blades more than $5 \mathrm{~cm}$ long... $T$. betsileensis

1'. Rhizomatous (rhizomes elongated); leaves on leafy culms, most leaf blades less than $5 \mathrm{~cm}$ long.....

2. Leaf blades $1-2.5 \mathrm{~mm}$ wide at base; apical lobes of the upper lemma c. $1 \mathrm{~mm}$ long....... T. isalensis

2'. Leaf blades (2 -) $3-4.5 \mathrm{~mm}$ wide at base; apical lobes of the upper lemma $2-3 \mathrm{~mm}$ long. T. humbertii

Tristachya betsileensis A.Camus (1957: 160). Isalus betsileensis (A.Camus) J.B.Phipps (1966: 233). Type: Madagascar, Fianarantsoa: western slopes of the western Itremo mountains, on gneiss and quartz, 1500 1700 m, 17 Jan. 1955, Humbert 30085 (holotype P00446275!; isotypes K001323697! [fragment], P00446276!, P00446277!).

Tussock-forming perennial, the culms $30-70 \mathrm{~cm}$ tall. Rhizomes contracted, 3 - $4 \mathrm{~mm}$ wide. Culms sometimes branched, erect, glabrous, the leaves appearing basal. Basal leaf sheaths glabrescent. Leaf sheaths glabrous. Ligule a fringe of hairs (not bulbous-based). Leaf blades linear, rolled, $5-15 \mathrm{~cm}$ long, c. $1 \mathrm{~mm}$ wide at base, straight to gently curled, glabrous. Inflorescences unbranched, 4 $9 \mathrm{~cm}$ long, composed of $3-6$ triads of spikelets in a lax panicle with $1-2$ triads at the lowermost branching point. Inflorescence branches subtending the triads filiform, often curved. Spikelet triads 9-14 mm long not including awns. Lower glume 9 - 12 mm long, glabrous, with bulbousbased trichomes on the nerves and the area between the nerves. Upper glume and lower lemma glabrous. Upper lemma brown, hirsute in the lower c. $2 / 3$, the callus hirsute, with white callus hairs exceeding the base of the lemma, the lobes with a mucro $1-2 \mathrm{~mm}$ long. Awn $12-$ 15 mm. Fig. 2.

DISTRIBUTION. Madagascar: Fianarantsoa, Itremo Protected Area. Map 1.

SPECIMENS EXAMINED. MADAGASCAR. Fianarantsoa: Itremo massif, Andohantanimenaha, $1600 \mathrm{~m}, 25$ Feb. 2013, Vorontsova et al. 1003 (K, TAN); Itremo, April 1964, Bosser 19536 (P); Itremo, Andohatanimena, flanc de montagne avant d'entrer dans la forêt galérie, 1550 m, 19 Feb. 2014, Nanjarisoa et al. 144 (K, TAN).

HABITAT. Rare endemic restricted to open gneiss and quartzite outcrops at $1500-1700$ m altitude.
CONSERVATION STATUS. Assessed here as Critically Endangered (CR) due to its extent of occurrence below $100 \mathrm{~km}^{2}$, a total of just four known collections, and its apparent dependence on gneiss and quartz rocky habitats which are under direct threat from illegal mining both outside and within the Itremo Protected Area (IUCN 2001; Kew Madagascar Conservation Centre 2012).

NOTES. Unusual, easy to recognise bunchgrass. Its populations, habitats, relationships with grazers, and seed dispersal mechanisms remain poorly known and are in need of study.

Tristachya isalensis (A.Camus) Voronts. E Rakotom. comb. nov.

http:/ /www.ipni.org/urn:lsid:ipni.org:names:77219675-1

Isalus isalensis (A.Camus) J.B.Phipps (1966: 233). Danthoniopsis isalensis A.Camus (1958 : 245). Type: Madagascar, Toliara: Isalo, plateaus and valleys west of Ranohira, 800 - 1250 m, 29 Jan. - 10 April 1955, Humbert 28663 (holotype P00446278!; isotype P00446279!).

Creeping mat-forming perennial, the culms reaching up to $60-70 \mathrm{~cm}$ above ground level. Rhizomes usually at least $5 \mathrm{~cm}$ long, $2-5 \mathrm{~mm}$ wide. Culms not branched, prostrate or ascending, glabrous, with leaves evenly distributed over the culms. Basal leaf sheaths glabrescent. Leaf sheaths glabrous or with bulbousbased hairs on and near the margins. Ligule a fringe of hairs, sometimes with bulbous-based hairs around the ligule area. Leaf blades linear, flat or rolled, $1.5-5(-8)$ $\mathrm{cm}$ long, $1-2.5 \mathrm{~mm}$ wide at base, straight to gently curled, glabrescent to hirsute, often with bulbous-based hairs on and near the margins. Inflorescences un- 

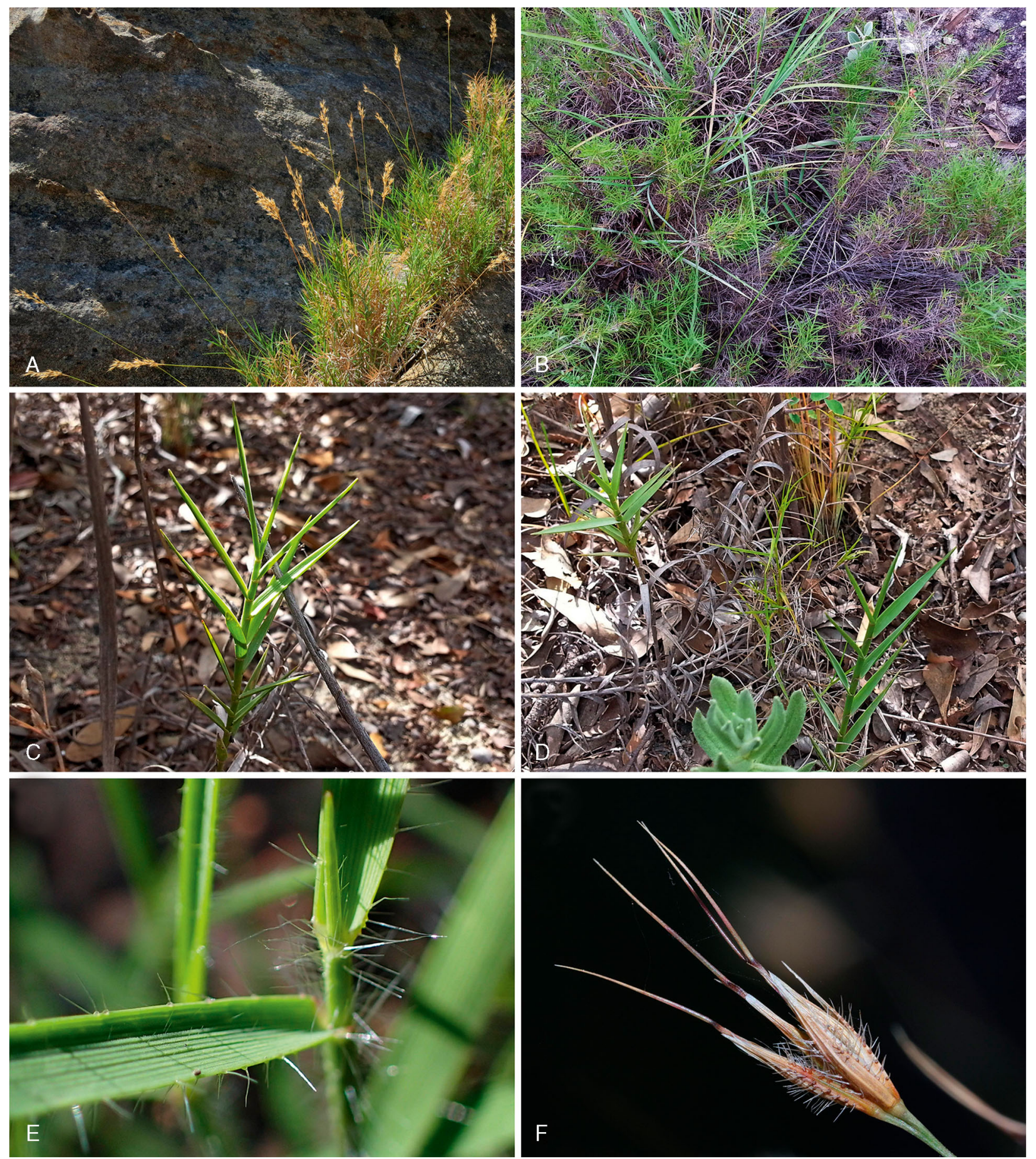

Fig. 1. Tristachya in the Isalo National Park, Madagascar: A, B, D, F Tristachya isalensis. C, D, E Tristachya humbertii. D young shoots of both species growing together: $T$. isalensis with narrow leaf blades is seen in the middle between $T$. humbertii with broader leaf blades. PHOTOS: A - E M. S. VORONTSOVA, F N. RAKOTOMALALA.

branched or branched, 4-11 cm long, composed of 315 triads of spikelets in a condensed panicle, the panicle branches opening at maturity with $1-6$ triads at the lowermost branching point. Inflorescence branches subtending the triads straight. Spikelet triads $8-12(-15)$ mm long not including awns. Lower glume $7.5-11.5(-17)$ $\mathrm{mm}$ long, glabrous, with bulbous-based trichomes on the nerves. Upper glume and lower lemma glabrous. Upper lemma white becoming brown, hirsute to glabrescent in the lower c. 2/3, the callus hirsute, with white callus hairs exceeding the base of the lemma, the lobes with a mucro $\mathrm{c}$. $1 \mathrm{~mm}$ long. Awn 10 - 17 mm. Figs 1A, B, D, F, 3, 4.

DISTRIBUTION. Madagascar: Fianarantsoa. Map 1. 


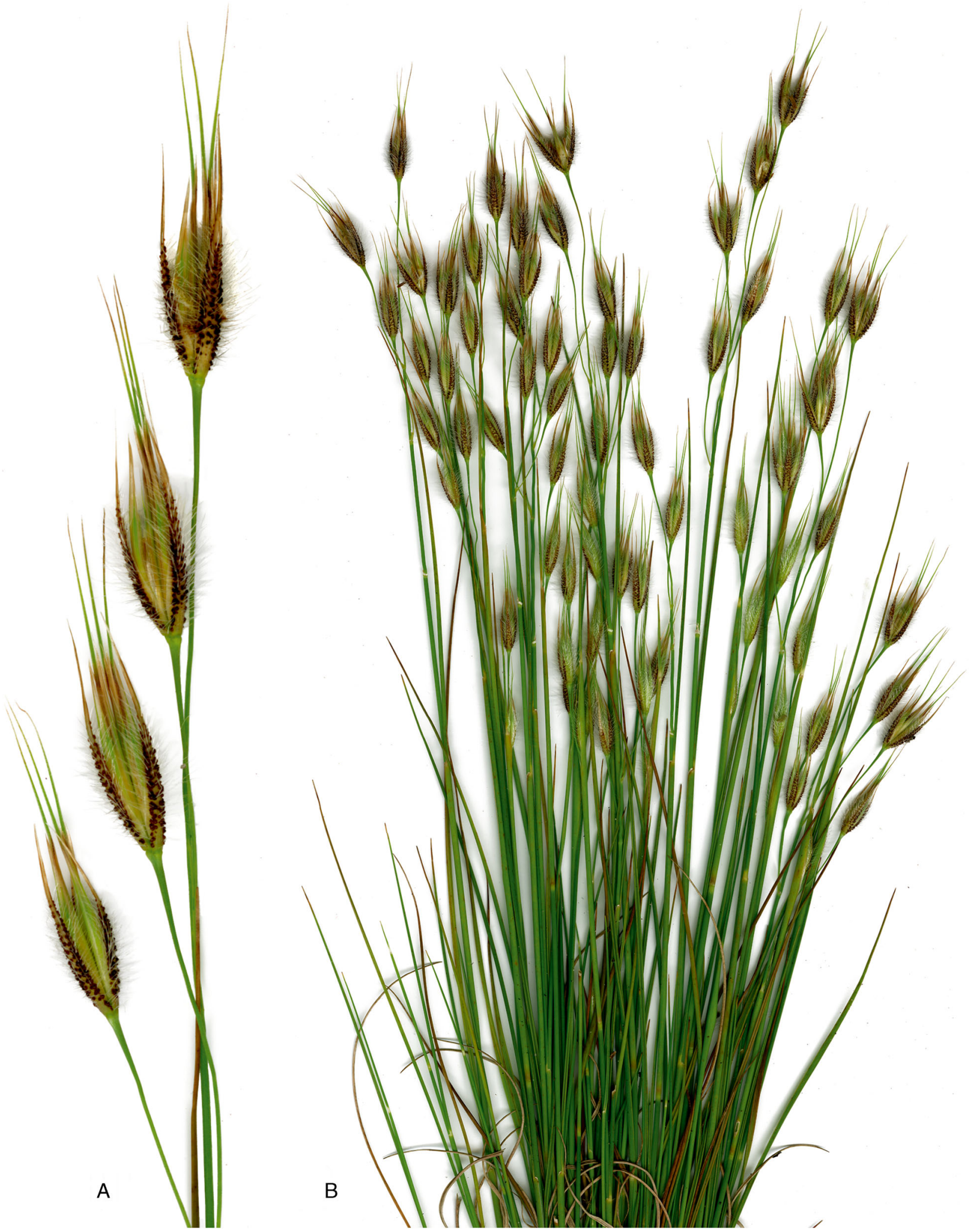

Fig. 2. Tristachya betsileensis. A spikelet triads; B habit. PHOTOS: M. S. VORONTSOVA, PLATE COMPOSITION: SARAH Z. FICINSKI.

SPECIMENS EXAMINED. MADAGASCAR. Fianarantsoa: sud de Madagascar, entre Ambalavao et l'Isalo, 14
Oct. 1970, Keraudren-Aymonin et al. 24657 (P); Isalo, 23 May 1930, Basse s.n. (P); Isalo, Feb. 1956, Bosser 8979 


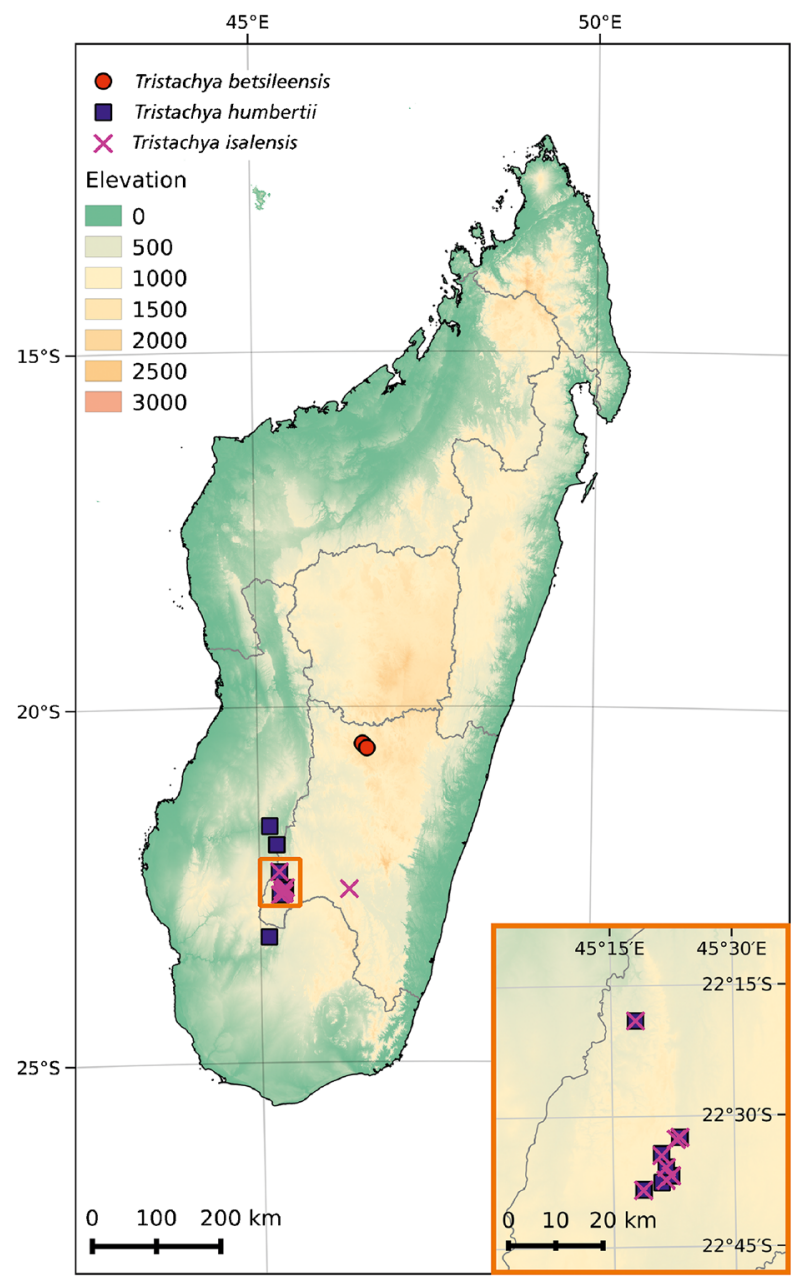

Map 1. Distribution of Tristachya in Madagascar. Elevation data from Jarvis et al. (2008). DRAWN BY SARAH Z. FICINSKI.

(P, TAN); col des tapias, Isalo, Dec. 1959, Bosser 13838 (P, TAN); Ilakatra, Isalo, Feb. 1962, Bosser 15623 (P, TAN); près de Ranohira, Isalo, Feb. 1962, Bosser 15628 (P); environs de Ranohira, Isalo, Dec. 1963, Bosser 17393 (P, TAN); Ranohira, Isalo, Jan. 1964, Bosser 19107 (P, TAN); col du Tapias, Isalo, 11 March 1970, Bosser 19891 (P); near Ranohira, Isalo, Feb. 1962, Bosser 15628 (TAN); Isalo, 3 July 1972, Bosser 8977 (TAN); District d'Ihosy, poste de Ranohira, entre Tametsoa et Sahanafo au nord de l'Isalo, Sahanafa, 700 - $1100 \mathrm{~m}$, 30 Jan. 1955, Cours 5063 (P); Isalo (Ranohira), 4 March 1943, Decary 18944 (P); plateaux et vallées de l'Isalo a l'Ouest de Ranohira, 800 - 1250 m, 29 Jan. 1955, Humbert 28663 (P); plateaux et vallées de l'Isalo a l'Ouest de Ranohira, 800 - 1250 m, 29 Jan. 1955, Humbert 29865 bis (P); 2e col des tapia (entre Ranohira et Sakaraha), 31 Oct. 1960, Leandri 3502 (P); 2e col des tapias (entre Ranohira et Sakaraha), 31 Oct. 1960, Leandri 3509 (P); 2e col des tapia (entre Ranohira et Sakaraha), même forme que 3502, 31 Oct. 1960, Leandri 3511 (P); Isalo, Feb. 1967,
Morat 2611 (P, TAN); col des tapias, Isalo, Feb. 1967, Morat 2612 (P); (Vohidolo côte $700 \mathrm{~m}$ ) entre la Menarahaka et Ihosy, 700 m, May 1973, Morat 4243 (P); Ilakaka (Isalo), 21 Feb. 1961, Peltier et al. 2986 [a] (P); Isalo National Park, trail to the Piscine Naturelle, $300 \mathrm{~m}$ from the car park, $875 \mathrm{~m}$, April 2018, Rakotomalala et al. 179 (TAN, K, P); Isalo, 18 April 1968, Rakotozafy 743 bis (P, TAN); near Isalo Interpretation Centre, outside Isalo Rock Lodge, 22 37'21"S, 45 21'27"E, 850 m, 26 Feb. 2017, Vorontsova et al. 2115 (TAN); Isalo National Park, Malaso circuit, W of Isalo

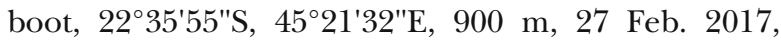
Vorontsova et al. 2145 (K, MO, P, TAN); Isalo National Park, end of the Malaso circuit towards the Malaso

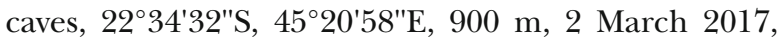
Vorontsova et al. 2187 (TAN); Isalo National Park, Fenetre de Isalo, 22 $38^{\prime} 28^{\prime \prime} \mathrm{S}, 45^{\circ} 18^{\prime} 41^{\prime \prime E}, 850 \mathrm{~m}, 2$ March 2017, Vorontsova et al. 2212 (TAN).

HABITAT. Sandstone outcrops and crevices, under tapia canopy as well as in open savanna; frequently burned habitats as well as those sheltered from fire; $700-1250 \mathrm{~m}$. CONSERVATION STATUS. Assessed here as Vulnerable (VU) due to its extent of occurrence below $5,000 \mathrm{~km}^{2}$, distribution apparently limited to sandstone substrates, and long-term protection within the boundaries of the Isalo National Park (IUCN 2001; Madagascar National Parks 2017).

NOTES. Tristachya isalensis is distinguished from T. humbertii by its narrower leaf blades. Tristachya isalensis and T. humbertii commonly occur together (Fig. 1D) and are frequently collected together. Tristachya isalensis has been collected more frequently than T. humbertii due to its apparently more common occurrence near the roads and paths of Isalo National Park - although it is less widespread across western Madagascar.

Tristachya humbertii A.Camus (1926: 401). Isalus humbertii (A.Camus) J.B.Phipps (1966: 233). Danthoniopsis humbertii (A.Camus) Conert (1957: 324). Type: Madagascar, Toliara: Isalo, Sakamarekely and Sambalinieto gorges, 500 - 100 m, 19 - 25 Oct. 1924, Humbert 2851 (holotype P00446280!; isotypes B 10 0168867!, G00022712!, GH00024562!, K001323699!, K001323700!, K001323701!, P00446281!, US00141971!).

Creeping mat-forming perennial, the culms reaching up to $30(-60) \mathrm{cm}$ above ground level. Rhizomes usually at least $5 \mathrm{~cm}$ long, $3.5-6 \mathrm{~mm}$ wide. Culms not branched, prostrate or ascending, glabrous, with leaves evenly distributed over the culms. Basal leaf sheaths hirsute. Leaf sheaths glabrous or with bulbousbased hairs on and near the margins. Ligule a fringe of hairs, sometimes with bulbous-based hairs around the ligule area. Leaf blades lanceolate, flat or rolled, 


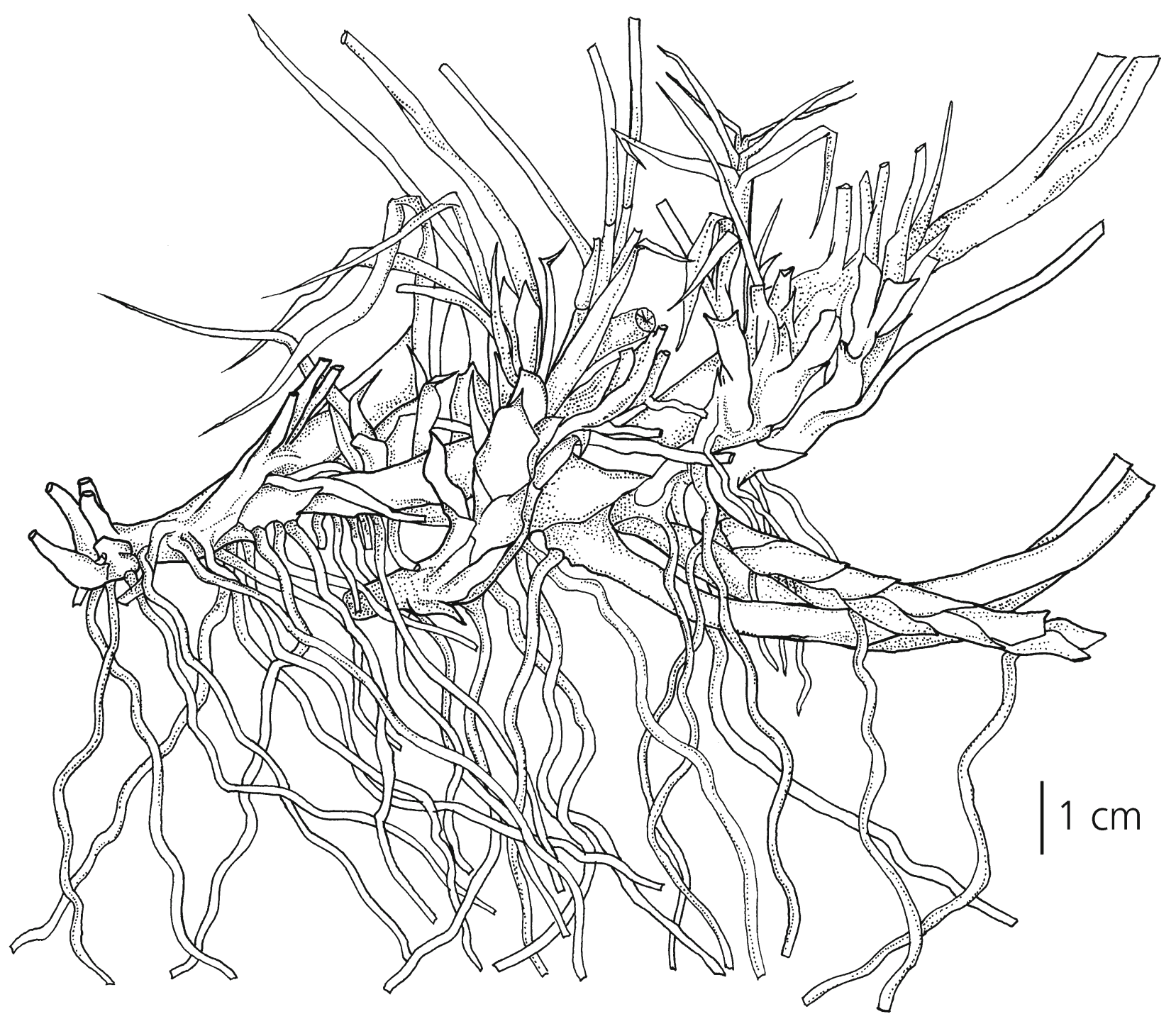

Fig. 3. Tristachya isalensis: plant base with knotty rhizomes and bases of culms. From Rakotomalala et al. 179. DRAWN BY N. RAKOTOMALALA.

2.5 - 5 (-6) cm long, (2 -) $3-4.5 \mathrm{~mm}$ wide at base, straight when young, stiff and curling back strongly with age, glabrescent to hirsute, often with bulbousbased hairs on the margins. Inflorescences unbranched, $6-11 \mathrm{~cm}$ long, composed of $10-12$ triads of spikelets in a lax to condensed panicle with $1-6$ triads at the lowermost branching point. Inflorescence branches subtending the triads straight. Spikelet triads $8.5-14 \mathrm{~mm}$ long not including awns. Lower glume (6.5 -) $9.5-13.5 \mathrm{~mm}$ long, glabrous, with bulbous-based trichomes on the nerves. Upper glume and lower lemma glabrous. Upper lemma brown, hirsute in the lower 2/3, the callus hirsute, with white callus hairs exceeding the base of the lemma, the lobes with a mucro $2-3 \mathrm{~mm}$ long. Awn 7-14 mm. Figs 1C, D, E, 5.

DISTRIBUTION. Madagascar: Fianarantsoa and Toliara. Map 1.
SPECIMENS EXAMINED. MADAGASCAR. Fianarantsoa: Isalo, Feb. 1956, Bosser 8978 (P); massif de l'Isalo, 31 Oct. 1940, Decary 16307 (P); bassin de la Malio près d'Ambalabe, 400 - 450 m, 23 Nov. 1946, Humbert 19388 (P); Isalo, 3 July 1972, Humbert 2891 (TAN); plateau de l'Isalo, col des tapias au S-W de Ranohira, 0 - 1000 m, Oct. 1933, Humbert 11216 (P); plateaux et vallées de l'Isalo, partie Nord, au S de Sahanafo, Sahanafa, 1000 m, 28 Nov. 1946, Humbert 19510 (P); Isalo, May 1965, Morat 1154 (P, TAN); col des tapias, Isalo, Feb. 1967, Morat 2613 (P, TAN); Isalo National Road, circuit Malaso, 878 m, 21 April 2018, Rakotomalala et al. 102 (K, TAN); Trachypogon grassland outside Isalo; c. $5 \mathrm{~km}$ from Ranohira towards Llakaka, 820 m, 20 April 2014, Vorontsova et al. 1369 (TAN); Isalo National Park, Malaso circuit W of Isalo boot, $900 \mathrm{~m}$, 27 Feb. 2017, Vorontsova et al. 2150 (K, MO, P, TAN); Isalo National Park, end of the Malaso circuit towards the Malaso caves, west Ampasimaiky, 850 m, 2 March 2017, Vorontsova 


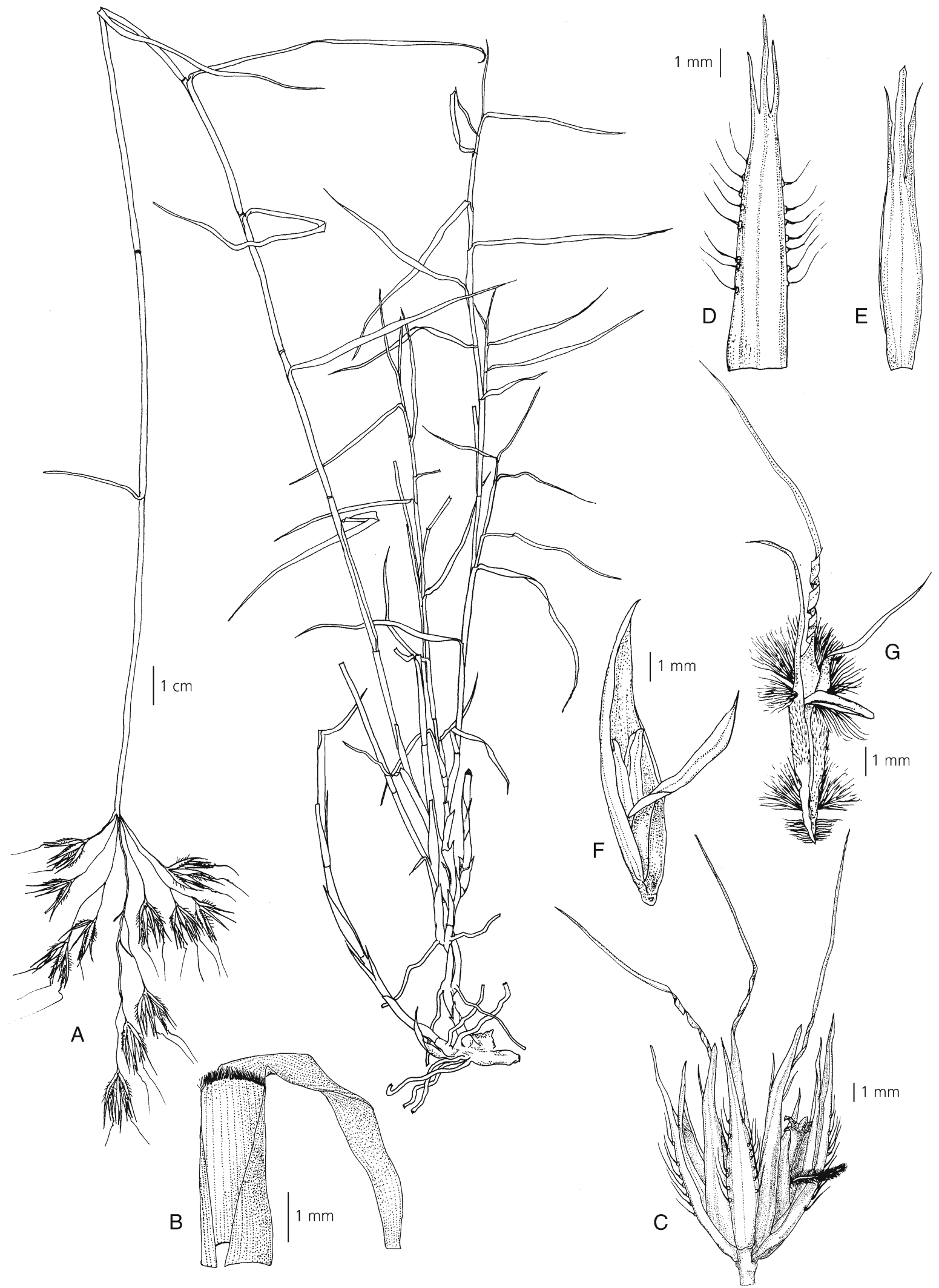

Fig. 4. Tristachya isalensis: A habit; B ligule; C spikelet triad; D lower glume, dorsal view; E upper glume, dorsal view; F lower floret, ventral view; G upper floret with bilobed awned lemma, ventral view. From Rakotomalala et al. 179. DRAWN BY N. RAKOTOMALALA, PLATE COMPOSITION BY SARAH Z. FICINSKI. 


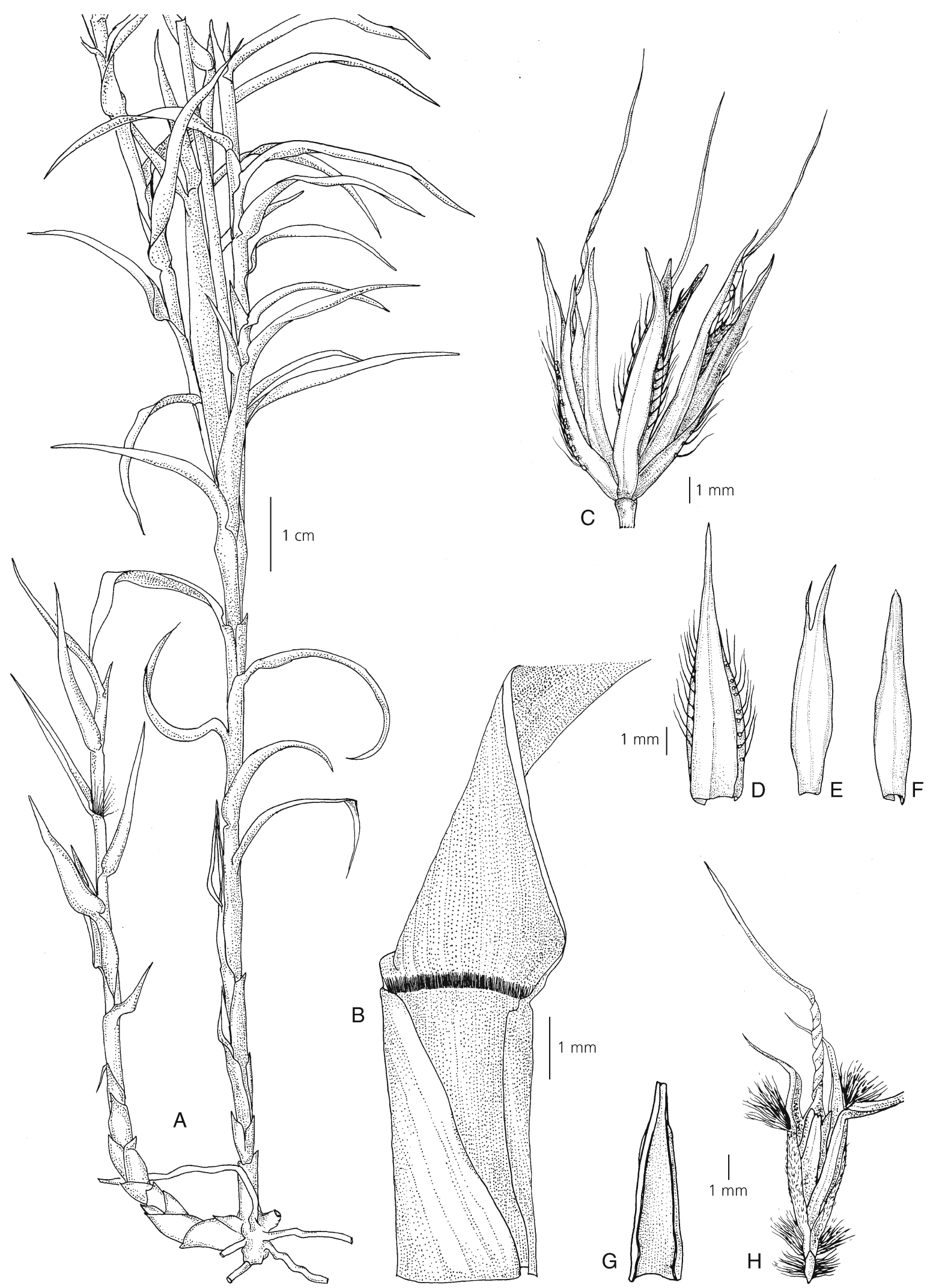

Fig. 5. Tristachya humbertii: A habit; B ligule; C spikelet triad; D lower glume, dorsal view; E upper glume, dorsal view; $\mathrm{F}$ lower lemma, dorsal view; G lower palea, ventral view; H upper floret with bilobed awned lemma, ventral view. From Rakotomalala et al. 102. DRAWN BY N. RAKOTOMALALA, PLATE COMPOSITION BY SARAH Z. FICINSKI. 
et al. 2190 (K, MO, P, TAN); Isalo National Park, Fenetre de Isalo, 850 m, 2 March 2017, Vorontsova et al. 2201 (TAN). Toliara: plateaux et vallées de l'Isalo, gorges de la Sakamarekely et de la Sambalinieto, Sakamarekely gorge, 700 - 1000 m, 19 Oct. 1924, Humbert 2851 (P); vallées du Mangoky et de l'Isahaina, aux environs de Beroroha, 0 300 m, Oct. 1933, Humbert 11351 (P).

HABITAT. Sandstone outcrops and crevices, under tapia canopy as well as in open savanna; frequently burned habitats as well as those sheltered from fire; $700-1000 \mathrm{~m}$.

CONSERVATION STATUS. Assessed here as Vulnerable (VU) due to its extent of occurrence below $5,000 \mathrm{~km}^{2}$, distribution apparently limited to sandstone substrates, and long-term protection within the boundaries of the Isalo National Park (IUCN 2001; Madagascar National Parks 2017).

NOTES. Tristachya humbertii is distinguished from T. isalensis by its broader and stiffer leaf blades that curl as the plant dries. It has a broader distribution across southwestern Madagascar.

\section{Acknowledgements}

Nantenaina Rakotomalala was supported by an Emily Holmes Memorial Scholarship granted by the AmarFranses \& Foster-Jenkins Trust via RBG Kew. Both authors thank Stuart Cable (RBG Kew) and everyone at the Kew Madagascar Conservation Centre (KMCC) for making this work possible. Nantenaina Rakotomalala would like to thank the botanical artists Masumi Yamanaka (RBG Kew), Christabel King (RBG Kew), and Agathe Haevermans (Muséum National d'Histoire Naturelle, Paris) for their assistance and art supplies. Thanks also to the Madagascar National Parks (MNP), Direction générale des forêts (DGF) and Parc Botanique et Zoologique de Tsimbazaza (PBZT) for granting research permits. Our field work in Itremo was supported by KMCC staff and field work in Isalo was supported by Andriantsitohaina Ranaivojaona, Ivon Tovondrainy, and Noel Randrianasolo (Madagascar National Parks). The authors would like to say thank you to Sarah Z. Ficinski for composing the plates and the map.

Open Access This article is licensed under a Creative Commons Attribution 4.0 International License, which permits use, sharing, adaptation, distribution and reproduction in any medium or format, as long as you give appropriate credit to the original author(s) and the source, provide a link to the Creative Commons licence, and indicate if changes were made. The images or other third party material in this article are included in the article's Creative Commons licence, unless indicated otherwise in a credit line to the material. If material is not included in the article's Creative Commons licence and your intended use is not permitted by statutory regulation or exceeds the permitted use, you will need to obtain permission directly from the copyright holder. To view a copy of this licence, visit http://creativecommons.org/ licenses/by/4.0/.

\section{References}

Bosser, J. M. (1969). Graminées des pâturages et des cultures à Madagascar. ORSTOM, Paris.

Camus, A. (1926). Graminées Nouvelles de Madagascar. Bull. Soc. Bot. France 73: 401 - 406.

(1957). Tristachya et Cyrtococcum nouveaux de Madagascar. Bull. Soc. Bot. France 104: 160 - 161. (1958). Espèces, sous-espèces et variétés nouvelles de Graminées malgaches. Bull. Soc. Bot. France 105: $244-246$.

(1960). Sur quelques Graminées malgaches. Bull. Soc. Bot. France 107: 209 - 211.

Clayton, W. D., Phillips, S. M. \& Renvoize, S. A. (1974). Flora of tropical East Africa. Gramineae. Part 2. Crown Agents for Oversea Governments and Administrations, London.

\& Renvoize, S. A. (1986). Genera Graminum: Grasses of the World. H.M.S.O., London. , Vorontsova, M. S., Harman, K. T. \& Williamson, H. (2016). GrassBase - The Online World Grass Flora. Kew: The Board of Trustees, Royal Botanic Gardens, Kew. http://www.kew.org/ data/grasses-db/index.htm. [Accessed 20 Dec. 2020].

Conert, H. J. (1957). Beiträge zur Monographie der Arundinelleae. Bot. Jahrb. Syst. 77: 226 - 354.

Edwards, E. J., Osborne, C. P., Strömberg, C. A., Smith, S. A. \& C4 Grasses Consortium. (2010). The origins of C4 grasslands: integrating evolutionary and ecosystem science. Science 328: 587 - 591.

Fish, L., Mashau, A. C., Moeaha, M. J. \& Nembudani, M. T. (2015). Identification guide to southern African grasses: An identification manual with keys, descriptions and distributions. South African National Biodiversity Institute, Pretoria.

Hackel, J., Vorontsova, M. S., Nanjarisoa, O. P., Hall, R. C., Razanatsoa, J., Malakasi, P. \& Besnard, G. (2018). Grass diversification in Madagascar: In situ radiation of two large $\mathrm{C} 3$ shade clades and support for a Miocene to Pliocene origin of C4 grassy biomes. J. Biogeogr. 45: 750 - 761. https://doi.org/ 10.1111/jbi.13147.

Hitchcock, A. S., Swallen, J. R. \& Chase, A. (1939). Poaceae (pars.) North American Flora 17 (8): 543 - 638.

IUCN (2001). IUCN Red List Categories and Criteria: Version 3.1. IUCN Species Survival Commission. IUCN, Gland \& Cambridge.

Jarvis, A., Reuter, H. I., Nelson, A. \& Guevara, E. (2008). Hole-filled seamless SRTM data V4. International Centre for Tropical Agriculture (CIAT). http://srtm.csi.cgiar.org. [Accessed 20 Dec. 2020]. 
Kellogg, E. A. (2015). Flowering plants. Monocots: Poaceae. In: K. Kubitzki (ed.), The families and genera of vascular plants, Vol. 13. Springer, Heidelberg.

Kew Madagascar Conservation Centre (2012). Plan d'Aménagement et de Gestion de la Nouvelle Aire Protégée du Massif d'Itremo, Ambatofinandrahana Région, Amoron'I Mania, Madagascar. Kew Madagascar Conservation Centre, Antananarivo.

Madagascar National Parks (2017). Plan d'aménagement et de Gestion. Plan quinquennal de mise en ouvre 2017 - 2021: Parc National d'Isalo. Régions Ihorombe et Atsimo Andrefana. Madagascar. Madagascar National Parks, Antananarivo.

Nanjarisoa, O. P., Besnard, G., Ralimanana, H., Jeannoda, V. \& Vorontsova, M. S. (2017). Grass survey of the Itremo Massif records endemic central highland grasses. Madagascar Conservation E Development, 12.

Nees von Esenbeck, C. G. D. (1829). Agrostologia Brasiliensis seu Descriptio Graminum in Imperio Brasiliensi hucusque Detectorum. In: C. F. P. von Martius (ed.), Flora Brasiliensis seu Enumeratio Plantarum 2 (1): 1 - 608. Stuttgartiae et Tubingae.

Phipps, J. B. (1966). Studies in the Arundinelleae (Gramineae), II. A new species and two new genera. Kirkia 5: 229 - 234.
Rakotomalala, N. H, Andriamanohera, M. A., Rabehevitra, D., Solofondranohatra, C. L., Jeannoda, V. H., Ranaivojaona, A., Ralimanana, H. \& Vorontsova, M. S. (2021). Grasses of the Isalo National Park, Madagascar - checklist, origins, and significance. Madagascar Conservation $\mathcal{E}^{\circ}$ Development 16, 1. https://doi.org/10.4314/mcd.v16i1

Sánchez-Ken, J. G. \& Clark, L. G. (2010). Phylogeny and a new tribal classification of the Panicoideae s.l. (Poaceae) based on plastid and nuclear sequence data and structural data. Amer. J. Bot. 97: 1732 - 1748.

Soreng, R. J., Peterson, P. M., Romaschenko, K., Davidse, G., Teisher, J. K., Clark, L. G., Barberá, P., Gillespie, L. J. \& Zuloaga, F. O. (2017). A worldwide phylogenetic classification of the Poaceae (Gramineae) II: An update and a comparison of two 2015 classifications. J. Syst. Evol. 55: 259 - 290.

\section{Publisher's Note}

Springer Nature remains neutral with regard to jurisdictional claims in published maps and institutional affiliations. 